\title{
The fragile 'absolute': Heremakhonon and the crisis of representation and historical consciousness
}

\author{
Rogers Asempasah ${ }^{1}$, Moussa Traore ${ }^{2}$ \\ ${ }^{I}$ (PhD Candidate, Department of English, University of Sapienza, Italy) \\ ${ }_{2}^{2}$ (Department of English, University of Cape Coast, Ghana)
}

\begin{abstract}
The Diasporian subject's encounter with Africa, framed around the trope of return to Africa, constitutes a crucial part of the poetics and discourse of Negritude and Afrocentrism. However, until Heremakhonon's intervention the condition of possibility of this trope was hardly contested and refuted. Drawing on Gilles Deleuze this article examines the criticality of encounter in Heremakhonon. Encounter in Heremakhonon emphasises experiential contact as a strategy for a radical tropological deconstruction of the return to Africa. We contend that Veronica Mercier's existential struggle in Heremakhonon dramatizes a broader crisis of representation and historical consciousness.
\end{abstract}

Key words: Afrocentrism, Conde, Deleuze, Encounter, Existentialism, Eurocentrism, Heremakhonon,

\section{INTRODUCTION}

Since its publication in 1976 Conde's Heremakhonon has occupied a seminal place in postcolonial discussions on Caribbean Francophone literary negotiations of history, memory, and the politics of rootlessness and rootedness within the broader context of Africa and the Diaspora. Much of the critical reception of Heremakhonon has therefore focused on the thematics of alienation and exile (Arlette 1988, 1991), failed quest (Morris 1997), heterogeneous time (Spivak 2005), transgenerational haunting (Bishop 2010) and the demystification of the trope of the return to Africa (2011). Critics are unanimous that it is impossible to understand Heremakhonon as a Caribbean literary event without locating it within the dominant political and literary narratives of Negritude and the valorisation of the return to Africa that framed Africa for the diaspora as "the name of the missing term, the great aporia, which [..] until recently, it lacked" (Hall 224). However, while this contextualisation has proven germane to explicating Heremakhonon's interrogation of Africa in the Diasporian imagination, the crucial function of encounter in the novel has only received passing commentary. This article therefore locates the counternarrative force of Heremakhonon in what Gilles Deleuze calls encounter. By emphasising the critical and transformative force of encounter, this article argues for a reading of Heremakhonon as an aesthetics of thinking otherwise. To think differently as Foucault contends is a refusal to legitimise "what is already known" (9). In other words we argue that what is at stake in Heremakhonon is not just the crisis of subjectivity or identity; it is, crucially, about the crisis of recognition and representation, and historical consciousness or memory. Only in this light can it be argued that Heremakhonon is a critique of Eurocentric and particularly Afrocentric representations of Africa. Problematizing Eurocentric and Afrocentric representations of Africa allow Conde to redistribute the sensible or logics in conceptualising and negotiating Caribbean Francophone subjectivity, identity and agency. We begin by focusing on Heremakhonon as a critique of Afrocentric and Eurocentric representations of Africa. Then in the second part we trace the problematic relationship between Francophone Africans and Afro-Caribbeans to French colonization. We conclude by suggesting that Heremakhonon shows that Caribbean Francophone subjectivity should be seen in terms of a triple consciousness.

\section{INTERROGATING AFROCENTRISM AND EUROCENTRISM}

Heremakhonon is the story of Veronica Mercier, a Guadeloupian-Caribbean philosophy teacher located in Paris, who decides to relocate to Africa, specifically an unidentified country in West Africa, as part of her attempt to reconnect with her "ancestors". She embodies a triple consciousness or heritage: Antillean, French and African. The organising trope of the novel revolves around the return to Africa. What is of significance, however, is that although Conde deploys this trope, it's constitutive force is radically delegitimised and shown to rest on mythology and orthodoxy. As Anne M. François argues, Heremakhonon's counternarrative resonance is not in the return to Africa trope per se but in the gender of the character or protagonist on this quest (x). By reversing the sex of the protagonist, much like the female Crusoe, Conde simultaneously undermines the normative construction of Africa as the originary motherland that bestows wholeness on a dispossessed and alienated consciousness. Representing Africa as masculine thus sets the stage for a problematic oedipal encounter. In a sense Conde's repetition of the trope of return to Africa can be described in terms of what Henry 
Louis Gates has called tropological revision. In The Signifying Monkey Gates argues that "tropological revision" refers to "the manner a specific trope is repeated with difference between two or more texts" (xxv). As Gates argues refiguration of tropes constitutes a critical heritage of black aesthetics of self-reflexivity, simultaneity and double-voicedness (xiv-xxviii). What is significant for the our argument here is Gates' insight that tropological revision functions either as "an act of homage" or critique (xxvii). Precisely in this sense of critique or rebuke, it could be argued that Conde's revision of the trope of return to Africa constitutes an instance of tropological revision. Although Gates framework provides a critical context for examining the thematics of intertextuality and double-voicedness in Heremakhonon, it is not a critique of representation and therefore its pertinence to the crisis of representation and historical consciousness is limited. It is to Deleuze then that we wish to turn. The advantage Deleuze offers is that he foregrounds encounter as a critique of recognition and representation. It is precisely this emphasis on encounter that we want to draw on to account for the crisis or what Veronica calls "tragic mistake" in Heremakhonon. Perhaps the point is worth emphasising at this point that our argument is not that Heremakhonon subscribes to Deleuze's radical antirepresentationalism. As Elizabeth Ermarth acknowledges "To speak at all, it seems, is to speak in "the language of representation" in which "we are inescapably engaged" (qtd in Cohen 13). What we posit as "crisis of representation" is not the rejection of representation and therefore does not translate into a rejection of language and signification (Cohen 13). Rather it seems to us that Deleuze's insight offers the possibility of exploring how Conde rejects Afrocentric and Eurocentric representations of Africa without necessarily crucifying or rejecting the language of representation.

For Deleuze "[r]epresentation has only a single centre... and in consequence a false depth. It mediates everything, but mobilises and moves nothing" (Deleuze 67). Is there a single centre in Veronica's Mercier quest? And what is its false depth? Veronica's description of her rediscovery project as a "tragic mistake", not only sums up her personal disillusionment; it encapsulates Conde's critique of the quest motif in Negritude discourse that is founded on recognition of the holy grail of authentic identity. The trope of the return to Africa is an essentialised paradigm that posits the plausibility of the rediscovery of a stable foundation with therapeutic force. It is here that the idea of recognition as a dominant orientation to our being-in-the-world emerges. In Difference and Repetition, Deleuze opposes encounter to recognition by arguing that recognition limits our capacity to think outside pre-established or hegemonic epistemologies and values. Recognition presupposes a model but this model, as Deleuze argues, is only a figure or image of thought "in which doxa is universalised by being elevated to rational level" (170). In other words, what is recognised is not only an object but the "established values" attached to the object (171). Precisely because recognition presupposes a model it legislates or engenders conformism and forecloses difference since in the end what is emphasised is a crude affirmation or rediscovery of what is already there. Recognition can therefore be said to be founded on phantasy, an archaeological quest or desire for the "blessed unspecified eternal object" (172). Because such conformism does not lead to the production of new modes of existence or subjectivities, Deleuze calls recognition "a dogmatic, orthodox image of thought" (167). To break with this monstrosity that imprisons the individual in the "same cave" where identity, opposition, analogy and resemblance are privileged elements, Deleuze declares that "[ $t]$ he conditions of a true critique and a true creation are the same: the destruction of an image of thought which presupposes itself and the genesis of the act of thinking in thought itself. Something in the world forces us to think. This something is an object not of recognition but of a fundamental encounter"(176). Conde's refiguration of the trope of return to Africa through her female protagonist, Veronica Mercier, can be read in Deleuzean terms as enacting a genuine encounter with Africa in which the dogmatic image of Africa constructed by Negritude and Afrocentrism is demythologized and in the process a radical rethinking of Caribbean Francophone identity is initiated. To validate this position we need to ask: what is the dogmatic image of thought Heremakhonon displaces? As we will show the dogmatic image of thought Conde deconstructs has the following postulates: Africa is home, the nurturing mother that provides stable foundations for the construction of Diasporian identity; Africa is the cradle of civilisation founded on a glorious past; a sense of shared historical and existential experience that can be unproblematically recuperated or reclaimed by the Diasporian.

Negritude and Afrocentric zeitgeist as exemplified in as diverse works as Aimé Césaire's Notebook of a Return to the Native Land (1939), Cheikh Anta Diop's The African Origin of Civilization: Myth or Reality (1955); Jean Price Mars's So Spoke the Uncle (1983) and Molefi Asante Kete's Afrocentricity: The Theory of Social Change (2003) politicize Africa as the cradle of humanity and civilisation, the ancestral home of blacks in the diaspora and the location of the panacea to the problems of alienation and rootlessness that constitute the identities of blacks in the Americas. This paradigm, it must be emphasised, is a response to the denigration of the past of oppressed Africans. As Fanon argued long ago one of the "perverted logics" of colonialism was that it did not only violently dehumanise colonial subjects, it also distorted, destroyed and disfigured their past. The result of this material and discursive violence on the colonised is a "passionate research ... directed by the secret hope of discovering beyond the misery of today, beyond self-contempt, resignation and abjuration, some very beautiful and splendid era whose existence rehabilitates us both in regard to ourselves and in regard to others" (169). It is here that Negritude and Afrocentrism become relevant; for they provide a mythology that reverses 
the position of Africa vis-à-vis Europe while maintaining the Manichaean vision of the world. Afrocentric emphasis on the return to Africa is thus a radical reversal of colonial estrangement which, in order to extinguish the desire of the enslaved to return to Africa, constructed the return as a regression into "barbarism, degradation and bestiality" (Fanon 169). The return to Africa by the Caribbean is therefore reconfigured as reconnecting and laying claim to a glorious heritage from which she had been violently dislocated by history. In Deleuzian terms, Africa becomes the absolute or model to which a return constitutes a strategic quest for recognition and authenticity. However, Heremakhonon adopts a drastically diametrical view and presents an Africa that is confronted with challenges related to the socio-economical and political exigencies of the modern world. In that respect, Heremakhonon strips Africa of the Afrocentric myth of exemplarity and makes bare the fragility of this model of Diasporian desire. Veronica finds herself in an ordinary post-independence African country where the newly elected African leader attempts to carve a third way between the Western and the Eastern blocks of the cold war era. Heremakhonon's West African nation-state is emerging from several decades of French colonial rule and Mwalimwana, the president, is a dictator who relies on tribalism and Marxist Leninist ideology to consolidate his power. Far from the utopian image of Africa in Negritude and Afrocentric discourse therefore, Veronica encounters an Africa that is patriarchally oppressive to the advancement of women, politically despotic and inimical to a democratic or dialogic public space, and historically and culturally indifferent to the tragedy of the history of slavery and the Diaspora. In fact one of the reasons Veronica eventually abandons Africa and returns to Paris is that the political culture thrives on deception, propaganda and the violent elimination of political opponents as presented in the killing of Birame III, one of Veronica's students, and the murder of Saliou, a strong opponent of the dictator and director of the school Veronica teaches. By constructing such an image of the Africa, Condé shows the limits of Afrocentrism.

But more importantly the radical interrogation of recognition or representation revolves around the protagonist Veronica. At the beginning of the novel Veronica Mercier's is careful to delineate the difference between her mission to Africa and the global interest in Africa as curio: "Honestly! You'd think I'm going because it is the in thing to do. Africa is very much the thing to do lately. Europeans and a good many others are writing volumes on the subject. Arts and craft centers are opening all over the Left Bank. Blondes are dying their lips with henna and running to the open market on the Mouffetard for their peppers and okra" (3). Veronica distances herself from this category whose interest in Africa has nothing to do with the essential issue of identity. As she puts it "Purpose of visit? No, I'm not a trader. Not a missionary. Not even a tourist. Well, perhaps a tourist, but one of a new breed, searching out herself, not landscapes" (3; emphasis mine). But the problem with this quest is that it blatantly ignores the differences in historical experiences and freezes Africa as an object to be rediscovered. We see this attitude in Veronica's framing of her encounter with Africa in terms of an analyst-analysand relationship. Africa, masculinized as Ibrahima Sory, becomes the analyst and Veronica Mercier the patient. As Veronica succinctly put it: "I'm an invalid, Mr. Minister, seeking therapy. I could tell you a lot" (26; emphasis mine). Veronica's expectation is that at the end of this encounter she will emerge "healed" and "reconciled with Africans and with herself" (56). Here we find at play what in psychoanalytic sessions Marc De Kessel has called "the formal structure of demand for help" (3). As Kessel points out "the analysand demands someone who will finally tell her why she feels so rotten, so unhappy, why the "good life" for which she yearns must so bitterly escape her" (2). It is this dogmatic image of thought at the heart of Negritude and Afrocentric representation of Africa that Heremakhonon dislodges by insisting not on the serenity and therapeutic figuration of Africa as motherland but on the constitutive violence of a genuine encounter with the Fatherland. By mediating her encounter with Africa in this analysand-analyst structure, Conde foregrounds the impossibility of Africa, Ibrahima Sory, to provide an answer to Veronica's problem and the impossibility of a "spontaneous empathy" between the patient and therapist. This is because, again as Kessel contends, psychoanalytic cure dispenses with "direct therapeutic communication" which means that the psychoanalytic session resists "the spontaneous empathy" that define other "normal" therapies (1). We can thus argue that Veronica's quest, in so far as it is underwritten by the structure of the analysand's demand for a "good life", or as Lacan put it, the desire "to identify with or be in conformity with some norm" (qtd in Kessel 4), is always already doomed to fail. Heremakhonon shows that Africa as the big Other for the Caribbean is a myth.

It is not surprising that Veronica's encounter with Ibrahima Sory assumes the form of an Oedipal crisis. In Africa as the fatherland violence takes multiple forms: the brutal liquidation of opponents, sexual and gender denigration, the violence of anagnorisis, and Africa's indifference to the historical memory slavery. That Africa is not the spatial location for Caribbean healing or happiness is signalled by the title, Heremakhonon. "Heremakhonon" in Malinke means "waiting for happiness". The Malinke are an ethnic group located in West Africa. At the same time "Heremakhonon" refers to a specific location, Ibrahima Sory's home. "Heremakhonon" as waiting for happiness thus marks Conde's direct refutation of Negritude mythology that Africa represents a happy home. That this is the case is not surprising since conditions in Heremakhonon, Ibrahima Sory's home, a microcosm or metonymy for Africa, are far from edifying or ideal. As Coetzee's Waiting for the Barbarians shows the motif of waiting constitutes a powerful technique for exploding stable 
constructs and normativity. The condition of "waiting" opens up an interregnum wherein the banality of the order of things is exposed and the disjunction between orthodoxy and reality forcefully articulated. As Paul Tillich rightly argues "waiting is not having" not having possessed or grasped (151). In that sense the moment of "waiting" makes bare the miasmatic or dystopic elements of despair, alienation, disappointment and abandonment that the ideological narrative elides. It would be wrong, however, to assume that this emphasis on "waiting" simply foregrounds pessimism. Far from that. Once again, as Coetzee's Waiting for the Barbarians shows the moment of waiting and its critique of constituted reality becomes the grounds for invoking the plausibility of a new praxis and a people. Tillich is therefore right when he argues that "waiting" is at once a moment of not having and having: "The fact that we wait for something shows that in some way we already possess it. Waiting anticipates that which is not yet real" (151). Although Tillich's emphasis is on waiting as constitutive of faith and man's relationship with God, it is significant to Conde's displacement of Africa as "home". In Heremakhonon Veronica's abandonment of Africa and return to Paris marks her realisation that the Africa represented by Negritude and Afrocentrism is fiction. But, more importantly, "waiting" opens the possibility for a broader conception of Caribbean subjectivity and identity. "Heremakhonon" as "waiting for happiness" thus suggests a displacement of the symbolic valence of Africa and the privileging of the Caribbean as the motherland.

Afrocentrism is not the only metanarrative that is interrogated by Conde. In fact, Heremakhonon also shows how Eurocentrism impedes the assertion of Caribbean Francophone identity, despite the clear position of the main protagonist and her unwavering commitment to her pro-African and pan-Africanist ideals. Although she often stands away from the self-denial that the French education system and life style inculcated in her, Veronica frames her relationship with Ibrahima Sory in Eurocentric terms. She calls Ibrahima Sory, Oroonoko. She explains her attraction to the man in these terms: "The truth is I am attracted to him, this nigger with ancestors" (28); she eventually appropriates him as "my nigger with ancestors" (35). This is where she becomes a victim of Afrocentric utopianism wherein the salvation of the black diasporan lies in Africa. Although Veronica is a cultural revolutionary who opposes Eurocentrism and Negritude ideology, her behavior often betrays traits of these ideological constructions of Africa that she tries to fight against. Veronica's search for a cure to her alienation draws her into more intimacy with Ibrahima Sory who, in her eyes, epitomizes freedom, the antithesis of slavery. She is attracted to him because his body does not bear the traces of slavery: "This man who is about to take me does not know that I am virgin of sorts. Of course the wrapper won't be stained with blood and the griott won't hold it up proudly to reassure the tribe. It will be another blood. Heavier and thicker. Before letting it flow, black and fast, I now realize why he fascinates me. He hasn't been branded." (35)

In Veronica Mercier's representation of Ibrahima Sory we see the convergence of the fatal duo: Eurocentrism and Afrocentrism. The symbolic power concentrated by Veronica's desire and invested in the African man is a consequence of the Eurocentric construction of the hypersexual African man, and also a of Afrocentric representation of Africa and Africans as the solution to the woes of the diaspora. The Eurocentric influence on Véronica's relationship with Ibrahima Sory manifests in the appellation she bestows on Ibrahima: Oroonoko. Oroonoko is, in fact, the name of Aphra Behn's handsome "royal" African slave in her eponymous work Oroonoko; or The Royal Slave, (1688). Véronica Mercier ironically assigns the name "Oroonoko" to Ibrahim Sory in order to mock her own naïve attraction to him and also to critique Behn's narrative. There are therefore parallels and radical discontinuities between the two narratives. The love affair between Véronica Mercier and Ibrahima Sory "the Oroonoko" therefore places Veronica and Aphra Behn on a par, and Veronica surprises herself by re-producing and re-enacting some of the Eurocentric practices: the attraction of the foreign woman-Veronica Mercier, the black Antillean woman who flees Paris, France, and Aphra Behn the British woman - to the body of the black man. Ibrahima Sory is seen by Veronica as the "gree-gree" that will cure and grace her with a new and better past, through a rebirth: "I came to find a cure. Ibrahima Sory, I know, will be the marabout's gree-gree. We'll exchange our childhoods and our past. Through him I shall at last be proud to be what I am. He wasn't branded. You can see that" (39). Her attitude can therefore be partly understood when one examines it in light of Fanon's analysis of Europe's construction of Africa among the Francophone Caribbeans. Fanon argues that in European discourse (which shapes the image of Africa and Africans in the mind of the Antillean child), the black man or male Negro simply becomes a phallic symbol: "one is no longer aware of the Negro but only of a penis; the Negro is eclipsed. He is turned into a penis. He is a penis" (170). But more than that, Conde's treatment of Aphra Behn's Oroonoko should be understood in terms of a radical critique. By relocating Behn's enslaved African, Oroonoko, from Surinam to Africa, Conde exposes not only the fantasy that underlies Behn's novella but the futility and naivety of Veronica Mercier's attempt to re-enact that romanticized construction of Africa. In fact, as Heremakhonon shows, although Ibrahima like Behn's Oroonoko is a descendant of nobility, he is no Oroonoko. What Veronica's encounter reveals is that the quest of the Caribbean for Oroonoko, the ideal model or essence, is problematic. As Deleuze contends in his critique of recognition "if it is a question of rediscovering at the end what was there in the beginning, if it is a question of recognising, of bringing to light or into the conceptual or the explicit what was simply known implicitly without concepts- 
whatever the complexity of this process, what the differences between the procedures of this or that author- the fact remains that all this is still too simple and...is truly not tortuous enough" (165). As we have seen Heremakhonon reaches a far more devastating conclusion: it is a "tragic mistake".

Also central to the invocation of Behn's Oroonoko in Heremakhonon is the issue of memory. The Francophone Caribbean context is special because although it has experienced the violence of plantation slavery, colonization and decolonization, that area also has the specific reputation of being "recolonized" through the French departmentalization policy of the DOMs (Departements d'Outre Mer or French Overseas Territories). Historical consciousness or the interrogation of memory is therefore crucial to identity construction. As Nick Nesbitt argues

The sheer violence, first of slavery and then of colonialism and neo-colonialist globalism, remains the driving impulse behind the French Antillean questioning of memory and history. Thanks to this historical specificity, the interrogation of memory on these small islands has been so acute that it may illuminate the more general dilemmas of modernity and memory structuring recent historical experience (4)

Veronica's firm questioning of memory and quest for a past appears in these lines: "That's mainly why I'm here. To try and find out what was before" (11). Véronica's "tragic mistake" is her assumption that Africa represents an undiluted identity location and that this can be unproblematically recuperated and claimed by the Caribbean Francophone as a home. But she ends up more alienated, treated as a sex object in the hands of the Ibrahima Sory, the man in whom she had put all her hopes. Ibrahima Sory makes Veronica see herself as a whore. The long and deep intellectual and personal dialogue or exchanges that she had expected from him never takes place:

So he doesn't want to know who I am, where I come from, what I've come to do so far from home? If he's not interested, if he doesn't ask, how can I call up my rab so that they leave me alone? He must help me find a cure. My hatred, my contempt. My explanations must be sincere-not like those patients who continue to lie to their psychiatrist. (48)

Ibrahima Sory, represented as Africa cannot understand Veronica's situation, as a Caribbean woman. He did not go through the experiences she went through growing up in the Caribbean and in Paris. Veronica is struck by Africa's indifference to the history of slavery. The indifference to the violence of slavery is manifested not only among Veronica's students but even at the very echelons of political leadership. When Veronica is introduced to Mwalimwana, the dictator, he says, "From the West Indies? Well, that's nice. One of the children that Africa lost..." (32;emphasis mine). Veronica is scandalized as lost not only trivializes the historical violence of slavery but it also absolves or denies the complicity of Africans in the slave trade. As Veronica silently counters "Sold, Mwalimwana, sold. Not lost. Tegbessu got 400 pounds sterling per boat load" (ibid; emphasis mine). Here we see the emergence of a "parallactic gap" regarding African and Afro-Caribbean conceptualisation of what slavery was and the status of enforced Diasporians. As Veronica would later admit "I didn't find my ancestors, three and a half centuries have separated me from them" (136). Were the Africans forcefully carted to the Americas lost or sold? Herein lies an ethico-political issue. To acknowledge the empirical fact of sold, is to open the epistemological and sensorial path to rememory as a therapeutic and the acceptance of radical vulnerability as the defining attitude to African and Diasporian subjectivity and identity. But this opportunity is foreclosed by Mwalimwana's logic of lost. This language of "lost" ignores the brutal economics or trade in human beings that was at the core of the Trans-Atlantic Slave Trade. For Veronica this failure of Africa to acknowledge and confront its role and duplicity in the enslavement of Africans shows that Africa cannot be a home, a place of happiness.

The fundamental difference in Veronica and Ibrahim personal experiences and backgrounds makes it impossible for Veronica and other Caribbean women protagonists such as Marie Hélène in Condé's other novel A Season in Rihata (1988) and Juletane in Mariam Warner-Vieyra's Juletane (1982) to be understood by their African lovers and husbands in a way that will lead to the realisation of their quest for self-discovery. The individualistic romantic assumptions of Veronica, Marie Hélène and Juletane reveal a Eurocentric influence that contrasts with the communal, unidealistic reality of gender relations in Africa. The disappointment that follows Veronica's love affair in Africa proves the limits of Afrocentrism. Continental Africans and Diasporan blacks have different experiences and backgrounds, despite their shared ancestry. Veronica discovers Africa, but not the Africa that she was longing for. Africa becomes like Europe with a black face for her. She also discovers that before her arrival in Heremakhonon, a young black American girl named Shirley had traveled the same path and received a treatment that was not better than hers. As Ibrahima Sory put it: "There was a young black American girl here who had the same sort of problem I believe. She ended up having her hair plaited like our women and having herself renamed Salamata" (49). Veronica's reflection on Shirley's situation contributes to locate these self-searching attempts and adventures explicitly within the context of the black diasporan women's disappointment in their identity quest in Africa: "What an amusing story! How it amuses him. I can imagine this poor Shirley alienated by white America and trying to cure herself. Amidst their laughter. Perhaps you made love to her? Perhaps you're the specialist for neurotics from the diaspora? We are after all the diaspora!"(48). 
Maryse Condé's heroines' quests are doomed because the Africa they had hoped would heal them cannot understand what the diasporan women need or are looking for. Ibrahima Sory's relationships with women are crude and superficial, as he reveals in a reference to Shirley when Veronica hints that he must have slept with her: "Oh no! My weak point is pretty women. And in the name of Allah she was very ugly!"(49).

III.

THE MISTRUST BETWEEN FRANCOPHONE AFRICANS AND FRANCOPHONE CARIBBEAN

Having examined the crisis at the heart of Heremakhonon, we now focus on the how colonialism has shaped relationship between continental Francophone Africans and Francophone Caribbeans. The identity crisis of people like Veronica Mercier reflects French colonial policy which portrayed Africa with negative stereotypes. Seeing themselves as more closely connected to France, some Antilleans did not want to be associated with Africa, and as a consequence, a mistrust settled between continental Africans and Antilleans. This mistrust and the rupture that it causes between continental Francophone Africans and the Francophone Caribbeans is what Heremakhonon stands against. The general mistrust between continental Africans and Caribbeans, especially within the period Heremakhonon was written was a widely known phenomenon. For instance, in his memoir La Plume raboutée, Birago Diop describes how he as a continental African would never associate with Francophone Caribbeans when he was a student in Paris because, in his opinion, all Francophone Caribbeans were des Martiniquais, des "Macafoutes" ( "je vais t'en $\mathrm{f} . .$. "), des "Macatjembes" ( je te tiens bien, je te visse"), c'est à dire, commis, gradés, administrateurs ou douaniers, des suppots du "colonialisme". (78) Martinicans, or "Macafoutes" (officers of the colonial administration). They were clerks, bosses, administrators or custom officers. They were all allies of colonialism.

Not only that. Julie Lirus refers to the alienation at the core of the French colonial education system in the Caribbean as "la pédagogie érronnée de la politique coloniale" (24) / the erroneous pedagogy of colonial policy. European world view is inculcated in the Antillean at an early age and as a consequence, the Antilleans, both males and females, grow up assimilating white French culture. As a result, the Francophone Caribbean portrayed Africa using the stereotypes that Europe associated with Africa: savages and backward people who needed the benevolence of Europe to enlighten them into "civilized ways." Julie Lirus's clinical study among Antillean students living in Paris on Francophone Caribbean identity crisis sheds light on what Africa represents for many Francophone Caribbeans. Some of the conclusions that Julie Lirus arrived at were the aggressiveness with which Caribbeans were trying to escape "blackness" in general and Africa in particular. She points out that in his effort to run away from "blackness", the Antillean man develops a "negrophobia":

En associant tout ce qui est pouvoir, richesse, puissance, à ce qui est blanc (échelle de valeur imposeé),

elle l'a rendu "négrophobe." A force de lui montrer qu'il est important socialement d'être blanc, elle lui a appris à avoir en horreur son épiderme fonce et à apprécier un individu en function de sa paleur épidermique. (31)

By associating everything that is power and wealth to whiteness (the yard stick requires it), he (the Antillean) developed "Negrophobia." He has been taught over and over again that it is socially important to be white and that led the Antillean to see horror in his dark skin, and to judge individuals, based on the lightness of their skin.

The distance between the African and the Antillean is illustrated by the use of the term "étranger" that Antilleans use to refer to the Africans: "Qualitativement, les Antillais étudiants rejettent aussi l'Africain, surtout les femmes. Ce rejet est illustré par l'usage du mot étranger"/ "Qualitatively, the Antillean students, especially the women also reject Africa. That rejection is illustrated by the use of the word foreigner" (95). Lirus recounts a conversation with two students who categorically rejected all connections to Africa: "Nous sommes différents en tout, c'est pour moi un étranger avec lequel je ne cherche même pas à voir ce qui nous rapproche" dit l'un des deux. / we are different at all levels, I see them ( Africans) as foreigners with whom I do not try to see what we have in common (95). Negrophobia leads the Francophone Caribbean to reject himself and his compatriots. Those with pronounced black features are called "nèg kongo" (Identité Antillaise 24) which means someone who is completely black without a drop of white blood. This term also refers to African slaves whom they consider as the image of the servitude they were subjected to. Furthermore, Lirus provides the following statistics: $86 \%$ of the respondents stated that they did not have any connection with Africa; $66 \%$ of them stated that there is a cultural difference between the Antillean and the African; $13 \%$ of them stressed the difference that exists between the personality of the African and that of the Antillean; and 10\% of the respondents (all women) stated that they could get along with African men because they were too possessive and authoritarian (94).

The representation of Africa as a primitive land in some works of Caribbean Francophone writers is the consequence of the education system that the French brought to their Caribbean territories and it is also the result of the fact that the French colonial administration needed some colonial administrators whom the metropole could not provide. That compelled the French government to recruit Francophone Caribbeans overseas for the administration of the colonial territories. As a result, Francophone Caribbeans found themselves ruling over African populations, on behalf of the French colonial master. In René Marran's Un homme pareil 
aux autres, Jean Veneuse, a Martinican, is urged to reach his administrative post in colonial Africa as soon as possible, because there is a lack of administrators, and he portrays the ship on which he travels to Africa as a "un cercueil"/ a coffin (16) and its destination "un sale pays où l'on s'ennuie a mort"/ a dirty country where one gets bored to death (33). In fact, the contrast that the book poses between life in Africa and life in Europe is as Eurocentric as Conrad's representation of Africa in Heart of Darkness. Un homme pareil aux autres associates Europe with books, sports and healthy life, while Africa is associated with ferocious animals and coconut trees: "les livres et le sport --escrime et rugby-- parmi les cocotiers, le sable, les bêtes féroces, les chameaux, les fonctionnaires coloniaux et un tas de bestiaux de même farine"/books and sport-escrime and rugby,-among coconut trees, the sand, wild animals, camels, colonial civil servants, and a whole bunch of beasts of the same kind (32). European education and the elevation of the Francophone Caribbean to the level of colonial administrator contributed to the negative representations of Africa in the works of Caribbean Francophone writers, and it also contributed to the mistrust between Africans and the Caribbeans. The Francophone Africans saw in the Caribbean an ally of the French colonizer.

Veronica's alienation is partly the result of these historical experiences. She views her relations with her sisters in terms of Cinderella's and her sisters. "As I've said, I and my sisters were like Cinderella and her sisters. We never liked each other" (Heremakhonon, 75). Unlike Cinderella however Ibrahima is no Prince and therefore there will be no romantic ending to Veronica's situation. Once again we see the repeated tendency in Heremakhonon wherein dominant motifs are invoked only to be destabilized. The self-hatred which is deeply rooted in Veronica emerges when she recalls that the French education system made her recite that she was from a race of brutes whose nose had to be permanently kept on the grinding mill: "Quant neg pas ka travail, I ka fe quimbois. When the nigger doesn't work, he casts spells" (77). In a way then we can see Veronica Mercier as a failed female Prometheus. Her mission to Africa was intended as finding the remedy to the alienation of the Caribbean Francophone woman. Despite this, her promethean side stands out clearly in the sense that she is the first in her community to attempt such a mission, and the result of her quest can be viewed as a praise-worthy achievement since it contributes to neutralizing or eliminating the illusions that Caribbean Francophone women had developed around Africa. She maintains an ironic perspective on her search for African roots even as she, nonetheless, embarks upon her quest to discover authentic identity. On the one hand, she embraces the Eurocentric stereotypes that associates African men with dangerous hypersexuality described by Fanon in Black Skin White Masks (157). For Veronica, this hint of dangerous sexuality is seductive, not threatening. She seeks it out in the hope of restoring an authentic African selfhood or sense of belonging. On the other hand, she also presents Africa as an eroticized, masculine continent that dominates the woman. In her relationship with Ibrahima Sory, she adopts a much more passive, submissive role than she had enacted in her previous life in the Caribbean and in Europe.

The interest that Caribbean women show towards Africa could also be traced to the influence of the Caribbean family itself. Families in the Antilles have been described by several researchers as "des familles de structure essentiellement matrifocale/ families with essentially matrifocal structures" (Identité Antillaise 39), or families in which the mother figure dominates, and the father figure is almost absent. Julie Lirus writes that "les pères brillent par leur absence /fathers' main characteristic is that they are missing", and she notes that $20 \%$ of the students who took part in the study she conducted among the Antilleans living in Paris had been brought up by single mothers, which is a significant percentage, considering the fact that most of those students were from relatively wealthy backgrounds where the assumed norm is to have a nuclear family structure (Lirus 83). David Macey recalls that Frantz Fanon was also raised in a matrifocal family where his father Casimir Fanon was almost effaced or absent, while his mother, Eléanore was the central authority figure. Macey provides a letter that Fanon wrote to his father in 1944-while he was fighting in the Second World War--, accusing him of irresponsibility and passivity. In the same letter Fanon attributes the success the family to his mother's strong commitment and self-sacrifice:

Papa, you really have sometimes failed to perform your duty as a father. I allow myself to judge you in this way because I am no longer of this earth. These are the reproaches of someone living in life's beyond. Sometimes Maman has been unhappy because of you. You made her unhappy enough. In future, you will try to return to her one hundredfold all she has done for the equilibrium of the family. The word now has a meaning that was previously unknown. If we, the eight children, have become something, Maman alone should take all the glory. She was the spirit. You were the arm. That is all. I can see the face you will pull when you read these lines, but it's the truth. Look at yourself. Look back at the years that have passed, lay your soul bare and have the courage to say: 'I deserted'. And then, repentant parishioner, you will be able to return to the altar. (Macey 57)

In "Two Caribbean Women Go to Africa," Adele King states that a form of serial polyandry exists in Guadeloupe, and as a consequence a woman may never marry, but have children from various lovers. This means therefore that the Caribbean boy and the Caribbean girl most of time grow up in an environment where the father figure is missing, in a sort of 'orphaned' society. The Caribbean woman who comes from a society 
where the father figure is missing may subconsciously seek that father figure whom she can hope to find in Africa, since she could not find him in her native Antilles and she cannot hope to find him in France where she is considered as a "négresse." Nancy Chodorow's (1978) work supports this view by stressing that the child's early relation with a woman has subsequent effects on the object-relations in the later developmental phases of the child: "Women's early mothering...creates specific conscious and unconscious attitudes or expectations in children. Girls and boys expect and assume women's unique capacities for sacrifice, caring, and mothering, and associate women with their own fears of regression and powerlessness. They fantasize more about men, and associate them with idealized virtues of growth" (83). Heremakhonon demonstrates that this quest for the father figure could have devastating consequences especially where there is a disconnect between the image of the father figured conjured and the figure that reality throws up.

Jonathan Ngate interprets Veronica's experience in Africa as an expression of Maryse Condé's personal attitude towards Africa. In Ngate's view, the failure of Veronica and Marie Hélène attempt to reconnect with Africa is a medium that Maryse Condé uses to show that "her feet are firmly rooted in the Antillean ground"(14) In "Maryse Condé and Africa: The Making of a Recalcitrant Daughter," Ngate recalls Maryse Condé's stance when it comes to the role of Africa in the West Indian's quest for identity. Condé believes that Africa is not needed in that quest:

La quête d'identité d'un Antillais peut très bien se resoudre sans passer, surtout physiquement, par

l'Afrique, ou si l'on veut, le passage en Afrique prouve simplement qu'elle n'est pas essentielle dans

l'identité antillaise.(Ngate14)

A West Indian's identity quest can very well be done without going through (especially physically)

Africa, or to put it another way, the passage through Africa simply means that Africa is not essential in the West Indian identity.

In an interview with VèVè Clark, Maryse Condé's position towards Africa becomes clearer. Conde refers to a "self-distancing" that has resulted in a "rejection of nostalgia in any form, rejection of historical, aesthetic, exotic or political preconceptions that tend to fetishize the past or slavery and to idealize political commitment, nature or the people; rejection of a self-pitying ideology that would reduce Guadeloupe to a marginal and oppressive land that one flees of necessity" (Clark ). Condé even directly blames the Negritude Movement for leading them (those from the Caribbean) into a futile search for origins, at the wrong place. Condé states that "the proponents of Negritude made a big mistake and caused a lot of suffering in the minds of the West Indian people and black Americans as well. We were led to believe that Africa was the source; it is the source, but we believed that we would find home there, when it was not a home. Without Negritude we would not have experienced the degree of disillusionment that we did" (ibid).

It would be wrong to classify Maryse Condé as someone who completely denies that there is an ancestral connection between Africa and the Francophone Caribbean. She points out that Africa could stand as the "mère adoptive" for the West Indians, for whom the West Indies would be the "mère naturelle" (Ngate 15). This might be the conclusion that Veronica arrived at after the rude awakening or disappointment she encountered in Africa. Veronica admits the error which her journey to Africa represents: "I didn't find my ancestors. Three and a half centuries have separated me from them. They didn't recognize me anymore than I recognized them. All I found was a man with ancestors who's guarding them jealously for himself and wouldn't dream of sharing them with me" (132).

\section{CONCLUSION}

In this paper we have argued that encounter is crucial to Conde's project of exposing the hollowness of the Negritude and Afrocentric ideology on Africa. Encounter functions simultaneously at the experiential level and as a critique of recognition and representation. By putting Africa as an ideal under interdiction, Heremakhonon calls for a redefinition of Afro-Caribbean relationship with Africa. That Conde's diagnosis of the problems of Africa are still relevant can be seen in the fact more than three decades after Heremakhonon was published conditions in Africa have grown worst. Perhaps both Africa and Afro-Caribbean are "waiting for happiness". But for the Caribbean that happiness is no longer located in Africa.

\section{REFERENCES}

[1] Arlette, Smith M. Maryse Conde's Heremakhonon: A Triangular Structure of Alienation, College Language Association Journal 321, 1988, 45-54. ---. The Semiotics of Exile in Maryse Conde's Fictional Works. Callaloo 14.2, 1991, 381-88. Behn, Aphra. Oroonoko: or, the Royal Slave (London: William Canning, 1688)

[3] Bishop, Elizabeth. "What I need to see life through rose-colored glasses is a good fuck": How a Performance of Ambivalent Sexuality Comes to Figure a Site of Metonymic Trangenerational Haunting in Maryse Conde's Heremakhonon in Thinking Gender Papers, UCLA Center for the Study of Women, UCLA 2010, http://escholarship.org/uc/item/4rb3d9mf

[4] Chodorow, Nancy. The Reproduction of Mothering: Psychoanalysis and the Sociology of Gender (Berkeley \& Los Angeles: University of California Press, 1978). 
[5] Condé, Maryse. Heremakhonon. Trans. Richard Philcox. (USA: Lynne Rienners Publishers Inc., 2000.[1976])___. “PanAfricanism, Feminism and Culture". Imagining Home: Class, Culture and Nationalism in the African Diaspora. Ed.Sidney Lemelle and Robin D.G. (Kelley. London: Verso, 1994)

[6] Cohen, Jesse S. Anarchism and the crisis of representation: Hermeneutics, aesthetics, politics (Selinsgrove: Susquehanna University Press, 2006)

[6] Diawara, Manthia. “Afro-Kitsch”. Black Popular Culture: A Project. Ed. Gina Dent and Michele Wallace (Seattle: Bay Press, 1992)

[7] Deleuze, Gilles. Difference and Repetition. Trans. Paul Patton. (London: Continuum, 2004)

[8] Diop, Birago. La plume raboutée (Paris: Présence Africaine, 1978)

[9] Fanon, Frantz. The Wretched of the Earth (New York: Grove Press, 1968)

[10] Foucault, Michel. The History of Sexuality, Vol. 2: The use of pleasure (USA: Vintage Books 1990)

[11] François, Anne M. Rewriting the return to Africa: voices of francophone Caribbean women writers (UK: Lexington Books, 2011)

[12] Gates, Henry Louis, Jr. The Signifying Monkey (New York, NY: OUP, 1988)

[13] Hall, Stuart. Cultural Identity and Diaspora, Colonial Discourse \& Postcolonial Theory: A Reader. Eds Williams, Patrick \& Laura Chrisman (Harvester Whaeatsheaf, 1993, 222-237)

[14] Kemedjio, Cilas and Ruthmarie H. Mitsch. Maryse Condé and West Indian Complexity: The Writing ofMonstrosity, Postcolonial Comparativism and Cannibalistic Intertextualities. Research in African Literatures 44(3), 2013, 176-189

[15] Kessel, Marc De. Eros and ethics: reading Jacques Lacan's Seminar VII. Trans. Sigi Jottkandt (USA: State University of New York, 2009)

[16] King, Adele. Two Caribbean Women Go to Africa. Maryse Condé's Heremakhonon and Myriam Warner- Vieyra's Juletane". College Literature.18(3),1991, 96-106.

[17] Lirus, Julie. Identité antillaise: contribution à la connaissance psychologique et anthropologique des Guadeloupeens et Martiniquais (Paris: Editions Caribéennes, 1979)

[18] Macey, David. Frantz Fanon: A Biography (New York: Picador, 2000)

[19 ]Maran, René. Un homme pareil aux autres (Paris: Editions Arc-en Ciel, 1947)

[20] Mars, Jean-Price. So Spoke the Uncle. Trans. Jean Fouchard and Magdaline W. Shannon (Washington: Three Continents Press, 1983)

[21] Morris, Daniel R. A 'Tragic Mistake?": Veronica's Identity Quest In Maryse Conde's Heremakhonon, Cincinnati Romance Review $x v i, 1997,24-31$

[22] Nesbitt, Nick. Voicing Memory: History and Subjectivity in French Caribbean Literature. (Charlottesville: University of Virginia Press, 2003)

[23] Ngate, Jonathan. Maryse Condé and Africa: The Making of a Recalcitrant Daughter. A Current Bibliography of African Affairs. $19.1(1986-87): 5-20$

[24] Nyatetu-Waigwa, wa Wangari. From Liminality to a Home of her Own? The Quest in Maryse Condé's Fiction. Callaloo18(3), 1995, 551-564.

[25] Simek, Nicole .Eating Well, Reading Well. Maryse Condé and the Ethics of Interpretation (New York: Rodopi, 2008)

[26] Spivak, Gayatri Chakravorty. The staging of time in Heremakhonon, Cultural Studies, 17(1), 2003, 85-97

[27] Warner-Vieyra, Mariam. Juletane. Paris: Presence Africaine, 1982 